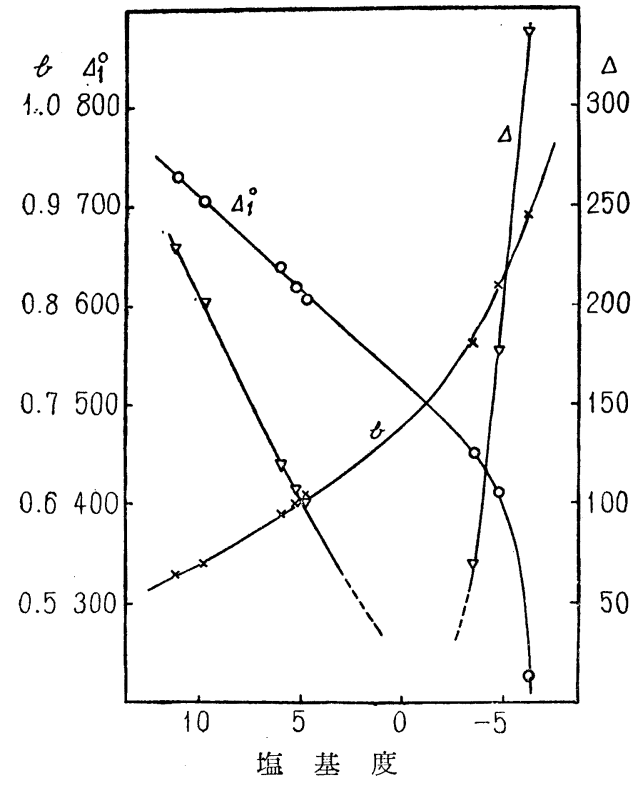

第 4 図 無掑動エネルギー準位の間隔 $\Delta$ とその自由 $\mathrm{OH}$ 吸収带からのずれ $\Delta_{1}{ }^{0}$ ならびに波動関 数の線形結合に括ける係数 $b$ と受容体の塩 基度との関係
帯からのずれで示せばそれぞれ第 1 表における $\Delta_{1}{ }^{0}$ むよ び $\boldsymbol{A}_{2}{ }^{0}$ で与えられるようになる。このようにして得られ た $\Delta, \Delta_{1}{ }^{0}$ および $b$ をそれぞれ縦軸に，受容体の塭基度 を横軸にとって図に描けば第 4 図に示すようになり，上 に述べた定性的な考察の正しいことを示している。

第 1 表に見られるように掑動エネルギーが割合大きく すべての試料に対してほぼ一定の值を示していることは 期待されるところであっで7, 得られた数値の妥当性な らびにとくに無掑動エネルギーの差 $\Delta$ が相対的強度比 $i$ がほぼ 1 にひとしい塭基に刘し極小值を有している事笑 は上に仮定した近似が制合妥当であることを示している ように思われる。

このようにして第 1 図掠よび第 2 図に示した特徴ある 变化をプロトン受容体の埧基性が增すにつれて二重極小 ポテンシァルの形が次第に移り変わって行く状態によっ て理解されるであろら。

本研究に際し絶えざる御指導御激励点賜わった藤岡由 夫教授ならびに御指竞をいただいた東大理工研長倉三郎 博士に感謝する。

*7 アンモニアの $2 \gamma_{2}$ 振動の反転二重分晟に刘する摄動エネルギーは 約 $157 \mathrm{~cm}^{-1}$ と得られる。

（東京学芸大学化学教室，東京都世田谷区）（昭和 32 年 11 月 16 日受理）

\title{
メタンの塩素・フッ素置換体における炭素ハロゲン 結合のイオン性について
}

\author{
浜 野 英一
}

メタンの塩素・フッ素置換体 $\mathrm{CH}_{2} \mathrm{FCl}, \mathrm{CHF}_{2} \mathrm{Cl}, \mathrm{CHFCl}_{2}, \mathrm{CF}_{3} \mathrm{Cl}, \mathrm{CF}_{2} \mathrm{Cl}_{2}, \mathrm{CFCl}_{3}$ に打沫 $\mathrm{C}-\mathrm{F}, \mathrm{C}-\mathrm{Cl}$ 結合のイオン性は双極子モーメントからは推察できない。ここでは経験的な原子価結 合法を用いててれらの結合のイオン性を求め，乙れら分子の核四極結合定数扔よび核磁気共鳴吸収 に扔ける化学シフトの值と比較するととにより，とれら分子に扔ける C-F，C-Cl 結合の性質を明 らかにした。その結果てれら分子の核四極結合定数挹よび化学シフトはそれぞれ $\mathrm{C}-\mathrm{F}, \mathrm{C}-\mathrm{Cl}$ 結合 のイオン性に大きく依存するととがわかった。さらに $\mathrm{CCl}_{4}$ 打よび $\mathrm{CH}_{3} \mathrm{~F}, \mathrm{CH}_{2} \mathrm{~F}_{2}, \mathrm{CHF}_{3}, \mathrm{CF}_{4}$ の各分子についても同様の考察を行い，核四極結合定数扣よび化学シフトとの関係が前記分子と類 似のものであることが確かめられた。

\section{緒言}

核四極共鳴吸収から得られる核四極結合定数 $e Q q^{*}$ は その性質上その核の付近の電子雲にのみとくに大きく依 存することから，その原子の関係している結合の性格に
ついての知見をうることができる。 $\mathrm{C}-\mathrm{Cl}$ 結合のイオン 性と核四極結合定数 $e Q q$ との関連についてはすでにメ タンの塩素置換体1について諭じたが,ここでは $\mathrm{CF}_{3} \mathrm{Cl}$, $\mathrm{CF}_{2} \mathrm{Cl}_{2}, \mathrm{CFCl}_{3}, \mathrm{CCl}_{4}$ および $\mathrm{CH}_{2} \mathrm{FCl}, \mathrm{CHF}_{2} \mathrm{Cl}, \mathrm{CHFCl}_{2}$ について同様の考察を行った。

1) 浜野, 本誌 77,746 (1956). 
一方核磁気共鳴吸収における化学シフトは理論的取り 扱いの複雑な量で, その理論的な解析は Ramsey2)によ りなされたが実際の分子についての試みはほとんどなさ れてい椋。この量はいわゆる Ramsey の第 2 項の寄 与により核の近傍の電子のみならず，分子内の軌道電子 により定まる量で，その原子の関係している結合の性質 と直接の関係はないが，しかしながら ${ }^{19} \mathrm{~F}$ の化学シフト

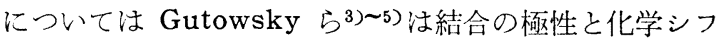
トとの平行関倸が多くの化合物についてかなりよく成立 つということを経験的にみいだした。

ここでは前記のメタンの塩素・フッ素置換体のみなら ず, $\mathrm{CH}_{3} \mathrm{~F}, \mathrm{CH}_{2} \mathrm{~F}_{2}, \mathrm{CHF}_{3}, \mathrm{CF}_{4}$ のフッ素置換体につい こも C-F 結合のイオン性と化学シフトとの関係が調ベ られた。

\section{結合のイオン性の理論}

著者はさきにメタンの塩素置換体1について経験的な 原子洒絬会法艺用いてその $\mathrm{C}-\mathrm{Cl}$ 結命のイオン性を論じ たがここではその理論安さらに一般化してメタンの塩 素・フッ素置換体のように多価中心原子、異種の原子が 結合した型の分子に適用することを試みた。

$\mathrm{CX}_{n} \mathrm{Y}_{m} \mathrm{Z}_{r}$ 型の化学的に同等な*1 $n$ 個の $\mathrm{C}-\mathrm{X}$ 結合お よび $\boldsymbol{m}$ 個の $\mathrm{C}-\mathrm{Y}$ 結合なる極性結合と，r個の純粋な共 有結合である $\mathrm{C}-\mathrm{Z}$ 結合をもつ分子における各 $\mathrm{C}-\mathrm{X}$, $\mathrm{C}-\mathrm{Y}$ 結合のイオン性を求めるのに際してつぎの仮定を した。

1）分子の原子解離熱は各結合の平均結合エネルギー の和と考える。

2 ）*2 分子中の各結合の平均エネルギーおよび共鳴エ ネルギー注分子に無関係に一定とみなす。

3) C-X, C-Y 結合は純粋な共有結合 C-Z が存在 してもそれらのイオン性法影響を受けない。

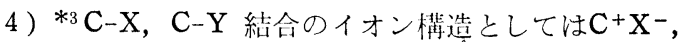
$\mathrm{C}+\mathrm{Y}-$ のみ考虑する。

5 ) *2 $\mathrm{C}-\mathrm{H}$ 結合はすべて純粋な共有結合とみなす。

2) N. F. Ramsey, Phys. Rev. 78, 699 (1950): 86, 242 (1952).

3) H. S. Gutowsky, C. J. Hcffman, J. Chem. Phys. 19, 1259 (1951).

4) H. S. Gutowsky, D. W. McCall, B. R. McGarvey, L. H. Meyer, J. Am. Chem. Soc. 74, 4809 (1952).

5) L. H. Meyer, H. S. Gutowsky, J. Phys. Chem. 57, 481 (1953).

*1とのととはメタンのフッ素畋换体について，核磁気共鳴吸収にお ける I.I. Coupling 5) から, C-F 結合が同等であることが確か められているが， $\mathrm{C}-\mathrm{Cl}$ 結合についても同様であろうと推察され る.

*2 交献 1) 参照.

*3 この仮定は C-F，C-Cl 結合についてはよい近似を与える。
これらの仮定にもとづいて $\mathrm{CX}_{n} \mathrm{Y}_{m} Z_{r}$ 型分子の波動 関数注

$$
\phi=a \psi_{c}+b_{n} \sum_{l=1}^{n} \psi_{i} \mathbf{X}+C_{m} \sum_{p=1}^{m} \phi_{i} \mathbf{Y}
$$

と書ける。ここで $\phi_{c}$ はこの分子の共有 結 合構造に, $\phi_{i l}^{\mathrm{X}}, \phi_{i p}^{\mathrm{X}}$ はそれぞれ $l$ 番目; $p$ 番目の $\mathrm{C}^{+} \mathrm{X}^{-}, \mathrm{C}^{+} \mathrm{Y}^{-}$ のイオン構造に対応する波動関数である。いま $\phi_{i l}$, $\phi_{i p}^{\mathrm{X}}$ 相互間の非直交性*4 を無視すれば,各 C-X, C-Y 結 合のイオン性 $\beta_{\mathbf{X}}, \quad \beta_{\mathbf{Y}}$ は規格化条件よりつぎのように 定義(6)される。

$$
\begin{aligned}
& \beta_{\mathbf{X}}=b_{n}{ }^{2}+a b_{n} S_{\mathrm{C} i l}, \\
& \beta_{\mathbf{X}}=c_{m}+a c_{m} S_{\mathrm{C}_{i} p} \\
& \text { ここで } \quad S_{\mathrm{C} i l}=\int \phi_{\mathrm{C}} \phi_{i l}^{\mathrm{X}} \mathrm{d} \tau, \quad S_{\mathrm{C}{ }^{p} p}=\int \phi_{\mathrm{C}} \phi_{i_{p}}^{\mathrm{X}} \mathrm{d} \tau
\end{aligned}
$$

$\phi_{i \mathrm{x}}=1 / \sqrt{n} \sum_{l=1}^{n} \phi_{i l}^{\mathrm{X}}, \phi_{i \mathrm{x}}=1 / \sqrt{m} \sum_{p=1}^{m} \phi_{i p}^{\mathrm{x}}$ とおけげ,

$$
\phi=a \psi_{\mathrm{C}}+b \psi_{i \mathrm{x}}+c \psi_{i \mathrm{x}}
$$

をうる。 $b=\sqrt{n} b_{n}, c=\sqrt{m} \mathrm{C}_{m}, S_{\mathrm{C} i \mathrm{x}}{ }^{* 5}=\sqrt{n} S_{\mathrm{C} i l}$,

$S_{\mathrm{C} i \mathrm{x}}{ }^{* 5}=\sqrt{\bar{m}} S_{\mathrm{C} i p}$ であるから，

$$
\begin{aligned}
& \beta_{\mathbf{X}}=\left(b^{2}+a b S_{\mathrm{C} i \mathrm{X}}\right) / n, \\
& \beta_{\mathbf{Y}}=\left(c^{2}+a c S_{\mathrm{C} i \mathrm{Y}}\right) / m
\end{aligned}
$$

永年方程式および規格化条件より $b^{2}+a b S_{\mathrm{Cix}}, \quad c^{2}+$ $a c S_{\mathrm{C} i \mathrm{Y}}$ が求められることから,

$$
\begin{aligned}
\beta_{\mathrm{X}} & =(1 / n)\left(1+L S_{\mathrm{C} i \mathrm{X}}\right) /\left(1+M^{2}+L^{2}\right. \\
& \left.+2 S_{\mathrm{C} i \mathrm{X}} L+2 S_{\mathrm{C} i \mathrm{X}} L M\right), \\
\beta_{\mathrm{Y}} & =(1 / m)\left[M\left(M+L S_{\mathrm{C} i \mathrm{X}}\right)\right] /\left(1+M^{2}+L^{2}\right. \\
& \left.+2 S_{\mathrm{C} i \mathrm{X}} L+2 S_{\mathrm{C} i \mathrm{Y}} L M\right)
\end{aligned}
$$

$$
\text { ここで, } M=\frac{\sqrt{\left.\left.H_{\mathrm{C} i \mathrm{x}}-S_{\mathrm{C} i \mathrm{x}} E\right)^{2}-\left(H_{\mathrm{CC}}-E\right) H_{i i \mathrm{x}}-E\right)}}{\sqrt{\left(H_{\mathrm{C} i \mathrm{x}}-S_{\mathrm{C} i \mathrm{Y}} E\right)^{2}-\left(H_{\mathrm{CC}}-E\right)\left(H_{i \mathrm{x}}-E\right)}}
$$$$
L=-\left[\left(H_{\mathrm{C} i \mathrm{x}}-S_{\mathrm{C} i \mathrm{x}} E\right)+M\left(H_{\mathrm{C} i \mathrm{X}}\right.\right.
$$$$
\left.\left.-S_{\mathrm{C} i \mathrm{Y}} E\right)\right] /\left(H_{\mathrm{CC}}-E\right)
$$

$$
H_{\mathrm{CC}}=\int \varphi_{\mathrm{C}} H \varphi_{\mathrm{c}} \mathrm{d} \tau \text {, }
$$

$$
\begin{array}{ll}
H_{\mathrm{C} i \mathrm{X}}=\int \phi_{\mathrm{C}} H \phi_{i \mathrm{x}} \mathrm{d} \tau, & H_{\mathrm{C} i \mathrm{Y}}=\int \phi_{\mathrm{C}} H \phi_{i \mathrm{Y}} \mathrm{d} \tau, \\
H_{i \mathrm{X}}=\int \phi_{i \mathrm{X}} H \phi_{i \mathrm{X}} \mathrm{d} \tau, & H_{i i \mathrm{Y}}=\int \phi_{i \mathrm{Y}} H \phi_{i \mathrm{X}} \mathrm{d} \tau,
\end{array}
$$

$E$ ：分子の解離エネルギー

これらの量は前報1)と同様の近似により単独の C-X, $\mathrm{C}-\mathrm{Y}$ 結合に関する量でつぎのように表わせる。

\footnotetext{
*4 ことでは $\mathrm{C}^{+} \mathrm{X}^{-}, \mathrm{C}^{+} \mathrm{Y}-$ のイオン構造のみを考慮しているから， これは小さいと考えられる。
}

6) R. S. Mulliken, J. Chim. Phys. 46, 497 (1949).

$*_{5} \quad S_{\mathrm{C} i \mathrm{X}}=\int \phi_{\mathrm{C}} \psi_{i \mathrm{X}} \mathrm{d} \tau, \quad S_{\mathrm{C} i \mathrm{Y}}=\int \phi_{\mathrm{C}} \psi_{i \mathrm{Y}} \mathrm{d} \tau$ 
$S_{\mathrm{C} i \mathrm{X}}=\sqrt{n} S_{0 \mathrm{C} i \mathrm{X}}, \quad S_{\mathrm{C} i \mathrm{Y}}=\sqrt{m} S_{0 \mathrm{C} i \mathrm{Y}}$,

$H_{\mathrm{CC}}-E=n R_{0 \mathrm{x}}+m R_{0 \mathrm{x}}$,

$H_{\mathrm{C} i \mathrm{X}}-S_{\mathrm{C} i \mathrm{X}} E=-V n\left[V R_{0 \mathrm{x}}\left(H_{0 i i \mathrm{x}}-E_{0 \mathrm{X}}\right)\right.$

$\left.+S_{0 \subseteq i \mathrm{X}}\left\{m R_{0 \mathrm{Y}}+(n-1) R_{0 \mathrm{X}}\right\}\right]$,

$H_{C i \mathrm{Y}}-S_{\mathrm{C} i \mathrm{Y}} E=-V m\left[V R_{0 \mathrm{Y}}\left(H_{0 i i \mathrm{Y}}-E_{0 \mathrm{Y}}\right)\right.$

$\left.+S_{0 \mathrm{C} i \mathrm{Y}}\left\{n R_{0 \mathrm{X}}+(m-1) R_{0 \mathrm{Y}}\right\}\right]$,

$H_{i i \mathrm{x}}-E=\left[V H_{0 i \mathrm{x}}-E_{0 \mathrm{x}}+(n-1) V R_{0 \mathrm{x}}\right.$

- $\left.S_{0 \mathrm{C} i \mathrm{X}}+m \vee \sqrt{0 \mathrm{Y}} \cdot S_{0 \mathrm{C} i \mathrm{Y}}\right]^{2}$,

$H_{i i \mathrm{Y}}-E=\left[\sqrt{H_{0 i i \mathrm{Y}}-E_{0 \mathrm{Y}}}+(m-1) \sqrt{R_{0 \mathrm{X}}}\right.$

- $\left.S_{0 \mathrm{C} i \mathrm{Y}}+n \sqrt{R_{0 \mathrm{X}}} \cdot S_{0 \mathrm{C} i \mathrm{X}}\right]^{2}$,

$R_{0 \mathrm{X}}=H_{0 \mathrm{CCX}}-\mathrm{E}_{0 \mathrm{X}}, \quad R_{0 \mathrm{X}}=H_{0 \mathrm{CCX}}-E_{0 \mathrm{Y}}$.

ここで $0 ， \mathrm{X} ， \mathrm{Y}$ をつた量はそれぞれ本来の $\mathrm{C}-\mathrm{X}$,

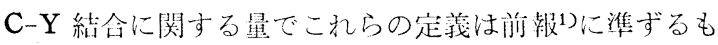
のである。

$\mathrm{C}-\mathrm{Cl}, \mathrm{C}-\mathrm{F}$ 結合についての計算に必要な $E_{0 \mathrm{Cl}}, E_{0 \mathrm{~F}}$, $R_{0 \mathrm{Cl}}, R_{0 \mathrm{~F}}, S_{0 \mathrm{C} i \mathrm{Cl}}, S_{0 \mathrm{C} i \mathrm{~F}}, H_{0 i i \mathrm{Cl}}, H_{0 i i \mathrm{~F}}$ の評何注つぎ のと标り。

1) $E_{0 \mathrm{Cl}}, E_{0 \mathrm{~F}}, R_{0 \mathrm{Cl} l}, R_{0 \mathrm{~F}}$

$E_{0 \mathrm{Cl}}, R_{0}$ こ1 については前報1)同じ值を採用し， $E_{0 \mathrm{~F}}$ ， $R_{0 \mathrm{~F}}$ 洞じ方法によりそれぞれ $93.2 \mathrm{kcal} / \mathrm{mol}^{7)}, 48.6$ $\mathrm{kcal} / \mathrm{mol}$ なる値を得た。

2) $H_{0 i i \mathrm{Cl}}, H_{0 i i \mathrm{~F}}$

前報1と同じく Born-Meyer の式879) を用いて求め た。必要な定数扎よび $\mathrm{C}-\mathrm{C} 1$ 結合についての諸量の值は 前報と同じである。C-F結合については $E_{\mathrm{F}}=3.63 \mathrm{eV}^{10}$ )

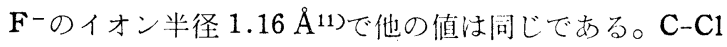

\section{第 1 表}

\begin{tabular}{l|c|c||c|c}
\hline \hline 分 & $r_{\mathrm{C}-\mathrm{F}}(\AA)$ & $r_{\mathrm{C}-\mathrm{Cl}}(\AA)$ & 分 & $r_{\mathrm{C}-\mathrm{F}}(\AA)$ \\
\hline $\mathrm{CH}_{2} \mathrm{FCl}$ & $1.40^{12)}$ & $1.76^{12)}$ & $\mathrm{CH}_{3} \mathrm{~F}$ & $\left.1.385^{14}\right)$ \\
$\mathrm{CHF}_{2} \mathrm{Cl}$ & $1.36^{12)}$ & $1.73^{12)}$ & $\mathrm{CH}_{2} \mathrm{~F}_{2}$ & $\left.1.358^{15}\right)$ \\
$\mathrm{CHFCl}_{2}$ & $1.41^{12)}$ & $1.73^{12)}$ & $\mathrm{CHF}_{3}$ & $\left.1.332^{16}\right)$ \\
$\mathrm{CF}_{3} \mathrm{Cl}$ & $1.328^{13)}$ & $1.740^{13)}$ & $\mathrm{CF}_{4}$ & $\left.1.322^{5}\right)$ \\
$\mathrm{CF}_{2} \mathrm{Cl}_{2}$ & $1.35^{12)}$ & $1.74^{12)}$ & - & - \\
$\mathrm{CFCl}_{3}$ & $1.40^{12)}$ & $1.76^{12)}$ & - & - \\
$\mathrm{CCl}_{4}$ & - & $1.755^{12)}$ & - & - \\
\hline
\end{tabular}

7) M. L. Huggins, J. Am. Chem. Soc. 75, 4123 (1953).

8) M. Born, J. E. Meyer, Z. Physik. 75, 1 (1932).

9) E. Warhurst, Trans. Faraday Soc. 45, 461 (1949).

10) H. A. Skinner, H. O. Pritchard, ibid. 49, 1254 (1953).

11) E. C. Baughan, M. Polanyi, ibid. 37, 648 (1941).

12) P. W. Allen, L. E. Sutton, Acta Cryst. 3, 46 (1950).

13) W. Gordy, W. V. Smith, R. F. Trambarulo, "Microwave Spectroscopy” p. 372 (1953) New York.

14) O. R. Gilliam, H. D. Edwards, W. Gordy, Phys. Rev. 75, 1014 (1949)

15) D. R. Lide, J. Am. Chem. Soc. 74, 3548 (1952).
C-F 結合の核荫距離 $\boldsymbol{r}$ の倘は第1 表に示してある。

3) $S_{0 \mathrm{C} i \mathrm{Cl}}, S_{0 \mathrm{C} i \mathrm{~F}}$

前報1)と同じす法で C-Cl, C-F 結合の重なり愫分上り

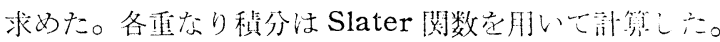

\section{理論の概要とその考察}

I. 核四極結合定数 $\boldsymbol{e Q \boldsymbol { q }}$ と $\mathrm{C}-\mathrm{Cl}$ 結合のイオン性 ここで取り扱うような分子の核四極結介这数 $e Q q$ 注 Gordy ら17)よ机代次式で表わされる。

$$
e Q q=(1-\alpha)(1-\beta) e Q q_{\mathrm{atom}}
$$

ここで $\alpha$ はその原子の絬合轨通における $s$ character $\beta$ 法その原子の関倸与る結命のイオン性， $e Q q_{\text {atom }}$ は二

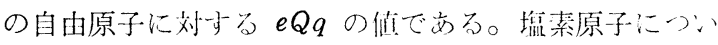
ての $e Q q_{\text {atom }}$ は $-109.74 \mathrm{Mc}^{18)}$ という任が得ら扎二い る。

$\mathrm{CF}_{3} \mathrm{Cl}, \mathrm{CF}_{2} \mathrm{Cl}_{2}, \mathrm{CFCl}_{3}, \mathrm{CF}_{4}$ の各分子の直態に扮行 る $|e Q q|$ の储注 $\left.77.58 \mathrm{Mc}^{17)}, 78.16 \mathrm{Mc}^{17)}, 79.63 \mathrm{Mc}^{17}\right)$ $81.85 \mathrm{Mc}^{17}$ で， $\mathrm{C}-\mathrm{Cl}$ 䋽会の数の增大と共に周波数が 増大している。 $\mathrm{CH}_{2} \mathrm{FCl}, \mathrm{CHF}_{2} \mathrm{Cl}, \mathrm{CHFCl}_{2}$ の行分子 の固態における $|e Q q|$ の值は $67.6 \mathrm{Mc}^{17)}, 70.50 \mathrm{Mc}^{17}$ ),

$\left.73.53 \mathrm{Mc}^{17}\right)$ である。父態に打ける $e Q q$ の值は $\mathrm{CF}_{3} \mathrm{Cl}$ については -78.05 $\left.\mathrm{Mc}^{17}\right), \mathrm{CH}_{2} \mathrm{FCl}$ については-70.48 $\mathrm{Mc}^{19)}$ と得られているのみで, 他の分子については現在 知られていない。固態と父態における $e Q q$ の愛は前者 では小さく，後者ではかなり大きい。今閔題上するのは 自由分子すなわ父態の $e Q q$ の值であるが，この上う に固態と父態に扮ける $e Q q$ の差が分子によって異なる ので，固態に打ける $e Q q$ の估を採用することはできな い。そこでここでは前者の気態の值を 4 分子の系列の基 準に取り，後者を後の 3 分子の系列の基準として塩秦の 結合軌道に抄ける $s$ character $\alpha_{\mathrm{Cl}}$ の值を定めた。つ ッ素の結合軌道に打ける混成法一応 $s$ character $\alpha_{\mathrm{F}}$ を $0 \%$ および $5 \%$ と仮定して, 前述の理諭により $\mathrm{C}-\mathrm{Cl}$ 結 合のイオン性 $\beta_{\mathrm{Cl}}, \mathrm{C}-\mathrm{F}$ 結合のイオン性 $\beta_{\mathrm{F}}$ 安訃算し た。得られた結果は第 2 表に示す。この際基準とした $\mathrm{CF}_{3} \mathrm{Cl}$ および $\mathrm{CH}_{2} \mathrm{FCl}$ における $\alpha_{\mathrm{Cl}}$ の得られた值*6 $\alpha_{\mathrm{F}}=0$ のとき, おのおの $\alpha_{\mathrm{Cl}}=0.21, \alpha_{\mathrm{Cl}}=0.25$ で, $\alpha_{\mathrm{F}}=$ 0.05 のとき扩のおの $\alpha_{\mathrm{Cl}}=0.23, \alpha_{\mathrm{Cl}}=0.26$ である。 $\alpha_{\mathrm{F}}=0.05$ のとき $\mathrm{CF}_{3} \mathrm{Cl}$ 以下の 4 分子の $\beta_{\mathrm{Cl}}$ の值はえ の $e Q q$ の值から考元て， $\alpha_{\mathrm{Cl}}$ の変化老考虑しても受入

16) S. N. Ghosh, R. Trambarulo, W. Gordy, J. Chem. Phys. 20, 605 (1952).

17）交㫦 13) 参照.

18) V. Jaccarino, J. G. King, Phys. Rev. 83, 471 (1951).

19) H. C. Allen, J. Phys. Chem. 57, 501 (1953).

*5（1）式を用いて気隹になける $\mathrm{eQ} q$ の夷测值に合うように定めた。 
第 2 表メタンの塩素・フッ素置換体に扣ける $\mathrm{C}-\mathrm{Cl}$ 結合のイオン性 $\beta_{\mathrm{Cl} 1}$ 打よび $\mathrm{C}-\mathrm{F}$ 結合のイオン性 $\beta_{\mathrm{F}}$

\begin{tabular}{l|c|c|c|c}
\hline \multirow{2}{*}{ 子 } & \multicolumn{2}{|c|}{$\alpha_{\mathrm{F}=0}$} & \multicolumn{2}{c}{$\alpha_{\mathrm{F}}=0.05$} \\
& $\beta_{\mathrm{Cl}}(\%)$ & $\beta_{\mathrm{F}}(\%)$ & $\beta_{\mathrm{Cl}}(\%)$ & $\beta_{\mathrm{F}}(\%)$ \\
\hline $\mathrm{CCl}_{4}$ & 7.1 & - & 7.1 & - \\
$\mathrm{CFCl}_{3}$ & 8.5 & 7.3 & 7.6 & 10.1 \\
$\mathrm{CF}_{2} \mathrm{Cl}_{2}$ & 9.4 & 7.9 & 8.0 & 9.5 \\
$\mathrm{CF}_{3} \mathrm{Cl}$ & 10.0 & 9.0 & 7.1 & 9.7 \\
\hline $\mathrm{CH}_{2} \mathrm{FCl}_{1}$ & 14.6 & 18.3 & 13.0 & 20.5 \\
$\mathrm{CHF}_{2} \mathrm{Cl}$ & 12.2 & 11.9 & 10.2 & 12.9 \\
$\mathrm{CHFCl}_{2}$ & 11.0 & 10.7 & 10.0 & 12.9 \\
\hline
\end{tabular}

れ難い值である。とくに $\mathrm{CCl}_{4}$ と $\mathrm{CF}_{3} \mathrm{Cl}$ が同じ $\beta_{\mathrm{Cl}}$ の 值をもつとは考光ら机ない。また $\mathrm{CF}_{2} \mathrm{Cl}_{2}$ の $\beta_{\mathrm{F}}$ の值 が $\mathrm{CF}_{3} \mathrm{Cl}$ と $\mathrm{CFCl}_{3}$ のそれらよりも小さくなるとは考 えられない。さらに $\alpha_{\mathrm{F}}=0.05$ 以上の值を取ると仮定し ても命理的落結果が得られないことからこれらの系列に ついては $\alpha_{F}=0$ に近いものと推察される。つぎ $\mathrm{CH}_{2} \mathrm{FCl}$ 以下の 3 分子の系列についても $\alpha_{\mathrm{F}}=0.05$ の場 合, $\mathrm{CHF}_{2} \mathrm{Cl}, \mathrm{CHFCl}_{2}$ の各 $\beta_{\mathrm{F}}$ の值が等しいとは考え られないのでこの系列についても $\alpha_{\mathrm{F}}=0$ に近いものと 考えるのが妥当である。

もしこ机ら 2 系列の分子においてそれぞれ基準とした 分子と同じ量の $s$ character $\alpha_{\mathrm{Cl}}$ をも方，固態および気 態に抒ける $e Q q$ の店が同じ程度であるとすれば，（1） 式によりそ机らの $e Q q$ の值は $\left(1-\beta_{\mathrm{Cl}}\right)$ に比例するはず である。事実第 1 濦に示されたようにこの関係は近似的 に成り立つと見てよい。それゆえメタンの塩素䈯換体に おいて示されたように $\alpha_{\mathrm{Cl}}=$ 一定という仮定は，この場 合にも一つの系列について近似的に成立ち $e Q q$ の值は

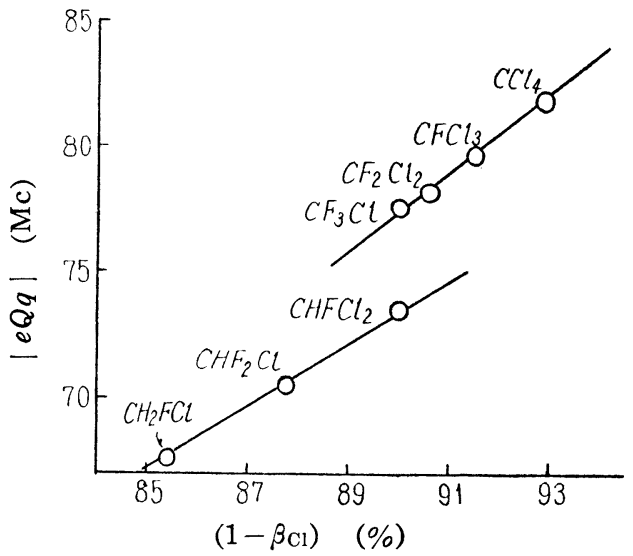

第 1 図
主として C--Cl 結合のイオン性に依存するということが できる。

以上の考察からメタンの塩素・フッ素置換体に㧊いて は $\alpha_{\mathrm{Cl}}$ の值はメタンの塩素置換体の場合*7 よりも增大 しており， $\alpha_{\mathrm{F}}$ の值はほとえど0に近いということがで きる。この結新はまた $\mathrm{CH}_{2} \mathrm{FCl} の \mathrm{C}-\mathrm{Cl}$ 結合のイオン 性が当然予想されるように $\mathrm{CH}_{3} \mathrm{Cl}$ のそれよりも小さい にもかか水らず $e Q q$ の值は逆低低事実を満足に説明 するものである。さらに興味あることは $\mathrm{CH}_{3} \mathrm{Cl} \rightarrow \mathrm{CH}_{2}$ $\mathrm{FCl} \rightarrow \mathrm{CHF}_{2} \mathrm{Cl} \rightarrow \mathrm{CF}_{3} \mathrm{Cl}, \mathrm{CH}_{2} \mathrm{Cl}_{2} \rightarrow \mathrm{CHFCl}_{2} \rightarrow \mathrm{CF}_{2} \mathrm{Cl}_{2}$ $\mathrm{CHCl}_{3} \rightarrow \mathrm{CFCl}_{3}$ のようにHを $\mathrm{F}$ 置換してゆくと第 2 表に示されたように $\mathrm{C}-\mathrm{Cl}$ 結合のイオン性は減少して ゆく*8。これはフッ素原子が水素原子よりも電気的に 陰性であることを考元れば当然の結果と考兄られるが， $\mathrm{CCl}_{4} \rightarrow \mathrm{CFCl}_{3} \rightarrow \mathrm{CF}_{2} \mathrm{Cl}_{2} \rightarrow \mathrm{CF}_{3} \mathrm{Cl}$ のように $\mathrm{Cl}$ を $\mathrm{F}$ で置 換してゆくと，フッ素原子は塩素原子よりも電気的に除 性であるにもかかわらず C-Cl 結合のイオン性は逆に増 してゆく。こ机は計算に用いた $E_{\mathrm{Cl}}=3.78 \mathrm{eV}^{1)}, E_{\mathrm{F}}=$ $3.63 \mathrm{eV}$ のように塩素の電子親和力はフッ素のそれより も大きいことに原因するものと思われる。

\section{II. 核磁気共鳴吸収における化学シフトと C-F 結合} のイオン性

核磁父共鳴吸収における化学シフト注普通 $\delta=\left(H_{r^{-}}\right.$ $\left.H_{c}\right) / H_{r} \times 10^{5}$ で测られる。ここで $H_{r}$ は基準とする化 合物中の其鳴磁場で， $H_{c}$ 汇問題とする化合物中の共鳴 磁場である。メタンのフッ素および塩素・フッ素置換体 の $\delta_{\mathrm{F}}$ の実測值5第 3 表に示す。

第 3 表 メタンのフッ素扔よび塩素・フッ素置換体の $\delta_{\mathrm{F}}$

\begin{tabular}{l|c||l|c} 
分 & \multicolumn{1}{|c|}{$\delta_{\mathrm{F}}$} & 分 & \multicolumn{1}{c|}{$\delta_{\mathrm{F}}$} \\
\hline $\mathrm{CH}_{3} \mathrm{~F}$ & -21.00 & $\mathrm{CF}_{3} \mathrm{Cl}$ & +3.68 \\
$\mathrm{CH}_{2} \mathrm{~F}_{2}$ & -8.09 & $\mathrm{CF}_{2} \mathrm{Cl}_{2}$ & +6.04 \\
$\mathrm{CHF}_{3}$ & -1.82 & $\mathrm{CFCl}_{3}$ & +7.67 \\
$\mathrm{CF}_{4}$ & 0.00 & & \\
\hline
\end{tabular}

化学シコト $\delta$ の解析は前述のように実際の分子につい

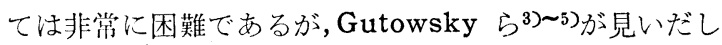
た経験的法則によれば， $\delta_{\mathrm{F}}$ の值は定性的に結合の極性 が增すほど負の大きな值を持つことになる。 $\delta_{\mathrm{H}}$ につい てはこのような簡単な関係はみいだされていない。

メタンのフッ素置換体における $\mathrm{C}-\mathrm{F}$ 結合と $\delta_{\mathrm{F}}$ との 関係を調べてみるために前述の䘏素・フッ素置換体のみ

*7 前報1)で得られた $\alpha \mathrm{Cl}$ の值は $17 \%$ であった.

*8 前報1)で得られた $\mathrm{CH}_{3} \mathrm{Cl}, \mathrm{CH}_{2} \mathrm{Cl}_{2}, \mathrm{CHCl}_{3}$ における各 $\beta \mathrm{Cl}$ の値は $17.1 \%, 11.7 \%, 8.8 \%$ である. 
ならず, $\mathrm{CH}_{3} \mathrm{~F}, \mathrm{CH}_{2} \mathrm{~F}_{2}, \mathrm{CHF}_{3}, \mathrm{CF}_{4}$ の各分子におけ る C-F 結合のイオン性を同じ理論を用いて計算した。 その結果は第 4 表に示す。

$\alpha_{\mathrm{F}}=0, \alpha_{\mathrm{F}}=0.05$ のいずれの場合が正しいかは塩素 フッ素置換体のように定められないが，その差は小さい

第 4 表 メタンのフッ素置換体に打ける C-F 結 合のイオン性 $\beta_{\mathrm{F}}$

\begin{tabular}{l|c|c||l|r|r}
\hline \multirow{2}{*}{ 分 } & \multicolumn{2}{|c|}{$\beta_{\mathrm{F}}(\%)$} & \multirow{2}{*}{ 分 子 } & \multicolumn{2}{|c}{$\beta_{\mathrm{F}}(\%)$} \\
\cline { 2 - 6 } & $\alpha_{\mathrm{F}}=0$ & $\begin{array}{c}\alpha_{\mathrm{F}}= \\
0.05\end{array}$ & & $\alpha_{\mathrm{F}}=0$ & $\begin{array}{c}\alpha_{\mathrm{F}}= \\
0.05\end{array}$ \\
\hline $\mathrm{CH}_{3} \mathrm{~F}$ & 33.4 & 34.4 & $\mathrm{CHF}_{3}$ & 13.0 & 12.7 \\
$\mathrm{CH}_{2} \mathrm{~F}_{2}$ & 19.0 & 18.8 & $\mathrm{CF}_{4}$ & 9.7 & 9.4 \\
\hline
\end{tabular}

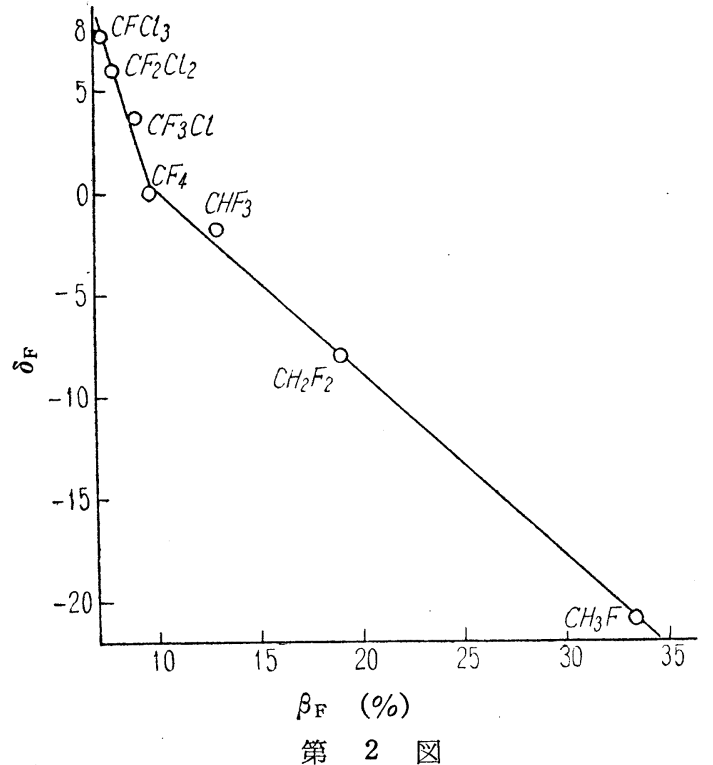

ので前と同様 $\alpha_{\mathrm{F}}=0$ の場合を採用すれば，C-F 結合の イオン性法第 2 表，第 4 表に示すように上記の期待と定 性的に一致する結果を与光る。すなわ占 $\delta_{\mathrm{F}}$ と $\beta_{\mathrm{F}}$ の平 行関係が確かめられたわけである。 $\delta_{\mathrm{F}}$ と $\beta_{\mathrm{F}}$ の関倸を 図示すれば第 2 図のようになり，フッ素置換体および塭 素フッ素置換体の 2 系列について上く直線関係が成立つ ことが示される。2 系列の直線の折れ曲りはイオン性以 外の因子に基ゔくものであろう。

以上の考察からメタンのフッ素置換体においては塩素 置換体と同㥞に同結合の数の増大とともに結合のイオン 性は減少してゆき, $\mathrm{CF}_{4}$ のフッ素原子を塩素原子でつぎ つぎ置換してゆくとやはり C-F 絬合のイオン性は減 少してゆくことがわかる。後の場合の理由について注前 節に述べたことによるものであろう。 $\mathrm{CH}_{2} \mathrm{FCl}, \mathrm{CHF}_{2} \mathrm{Cl}$, $\mathrm{CHFCl}_{2}$ の各分子については $\delta_{\mathrm{F}}$ の值は知られていない が，C-F結合のイオン性については前節の C-Cl 結合の 場合と同様の期待に合致するもので，いずれも合理的 な值を得た。

得られた結果から考えてフッ素原子の結合軌道はほとん ぞ純粋な $p$ 軌道と考えられるに反して, 塩素原子の軌道 にはかなりの $s$ character を考えなければならないが， これはエネルギー的な考察からも合理的なものである。 また第 2 表からわかるようにメタンのフッ素・塩素置換 体に打ける $\mathrm{C}-\mathrm{F}, \mathrm{C}-\mathrm{Cl}$ 結合を比較してみると，従来い われていたように C-F 結合が C-Cl 結合よりイオン性 が大きいとはかぎらす，分子によって事情㥩しく異な っている。この点双極子モーメントとも関連して興味あ る閭題であるう。

(昭和 32 年 10 月, 電子状態討論会講演)

（名古屋大学工学部応用化学教室，名古屋市千種区）（昭和 32 年 11 月 18 日受理）

\title{
水産 無脊椎動物 油脂の研究 (第 19 報 $)^{1)}$
}

\section{ヤッシロガイ油脂中の共役ステリン以外の不ヶン化物成分について}

\author{
田中立夫・外山修之
}

著者はさきにヤツシロガイ内藏油からの共役ステリン（蛙,7,22,25-コレスタテトラエノール）に ついて報告したが，今回ャッシロガイ肉油扣よび内藏油の非共役ステリン成分を検索し，また内藏 油についてはステリン以外の不ヶン化物成分を検索した。肉油および内臟油の非共役ステリンは主

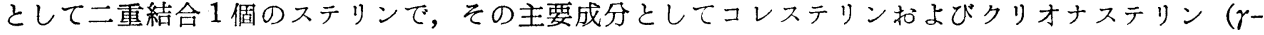
シトステリン）を分離するてとができた。肉油はコレステリンを多く含むが，内藏油はコレステリ 